\title{
PEMBELAJARAN PENGETAHUAN DASAR KOMPUTER BERBASIS BLENDED LEARNING PADA PROGRAM STUDI AGRIBISNIS STIPER AMUNTAI
}

\author{
Syaiful Arif \\ SMK Negeri 2 Amuntai Hulu Sungai Utara Kal-Sel \\ arif_pns@yahoo.com
}

\begin{abstract}
Abstrak
Penelitian ini bertujuan mengimplementasikan pembelajaran pengetahuan dasar komputer berbasis blended learning untuk meningkatkan motivasi, minat dan hasil belajar mahasiswa. Jenis penelitian ini menggunakan metode classroom action research yang dilaksanakan dalam 2 tahapan yaitu tahap pembuatan media learning dan tahap implementasi pembelajaran melalui 3 siklus proses pembelajaran dengan partisipan mahasiswa Program Studi Agribisnis STIPER Amuntai tahun akademik 2011/2012. Kegiatan siklus I meliputi perencanaan, tindakan, observasi, refleksi dan evaluasi. Kegiatan siklus II merupakan tindak lanjut dan modifikasi dari siklus I. Sedangkan siklus III adalah penyempurnaan dari siklus II. Instrumen dalam penelitian ini adalah, lembar observasi tindakan/siklus, lembar observasi motivasi dan lembar observasi minat. Validitas instrument dilakukan melalui expert judgement sedangkan reliabilitas instrument menggunakan teknik Cronbach Alpha kemudian analisis data penelitian menggunakan statistik deskriptif. Hasil penelitian menunjukkan bahwa melalui pembelajaran berbasis blended learning, terjadi peningkatan motivasi, minat dan hasil belajar. Adapun secara kuantitatif motivasi pada siklus I naik pada siklus II dan stabil pada siklus III. Sedangkan minat pada siklus I naik pada siklus II dan meningkat pada siklus 3. Ketercapaian hasil belajar ditunjukkan pada nilai tugas dan kuis siklus I naik pada siklus II dan meningkat pada siklus III. Ketercapaian ini menunjukkan bahwa mahasiswa sangat antusias dan aktif serta dapat meningkatkan hasil belajar.
\end{abstract}

Kata kunci: Motivasi, Minat dan Hasil Pembelajaran, Pengetahuan Dasar Komputer, Blended learning.

\section{THE LEARNING OF BASIC COMPUTER KNOWLEDGE BASED ON BLENDED LEARNING AT AGRIBISNIS PROGRAM STIPER AMUNTAI.}

\begin{abstract}
This research was aimed to implement the learning of basic computer knowledge based on blended learning to increase the motivation, interest, and learning achievement of the college students.

This research used the classroom action research method carried out within 2 stages including developing learning media and implementing stage. The stages follow 3 cycles of learning process with the participants from the students of Agrobusines Program STIPER Amuntai, academic year of 2011/2012. The activities in Cycle I consisted of: planning, actions, observations, reflections, and evaluation. The activities in Cycle II were the follow-up and modification from cycle I. Cycle III was the improvement of cycle II. Instruments of this reseach include: the action/cycle observation sheets, motivation observation sheets, and interest observation sheets. The validity of the instrument was obtained through the expert judgment, while the reliability of the instrument was measured by using Cronbach Alpha technique, and the data analysis was done by using descriptive statistics. The research results show that through the learning of basic computer knowledge based on blended learning, there is an increase in the motivation, interest, and the learning achievement. Quantitatively, motivation increas in Cycle I into Cycle II, and becomes stable in Cycle, while the interest increas from cycle I in Cycle II, and increas again in Cycle III. The accomplishment of learning result is shown from the score of tasks and quizzes, from cycle I increas in Cycle II, and increas again in Cycle III. This accomplishment show that students are very enthusiastic and active and also that the action can increase the learning achievement.
\end{abstract}

Keywords: Motivation, Interest, Learning achievement, Basic Computer Knowledge, Blended learning. 


\section{PENDAHULUAN}

Proses pembelajaran STIPER Amuntai masih konvensional dengan proses pembelajaran sehari-hari tatap muka (face to face) yang cenderung didominasi pengajar sebagai aktor utama. Sarana dan prasarana penunjang proses pembelajaran online STIPER Amuntai seperti tersedianya multimedia komputer, jaringan internet/hotspot, silabus, RPP dan materi bahan ajar diharapkan dapat mendukung peningkatan motivasi, minat dan hasil belajar.

Mahasiswa yang memprogram mata kuliah pengetahuan dasar komputer pada tahun ajaran 2011/2012 rata-rata mempunyai laptop pribadi yang setiap hari digunakan dalam proses belajar di kelas. Mahasiswa tersebut sudah pernah memprogram mata kuliah pengetahuan dasar komputer sebelumnya dengan nilai kurang baik. Dalam konteks demikian, diperlukan pendekatan pembelajaran blended learning dimana mahasiswa tidak hanya diajak untuk belajar formal tatap muka dalam situasi ruangan kelas, tetapi juga diajak untuk belajar dan berlatih secara online melalui internet.

Penelitian tindakan kelas ini merumuskan beberapa masalah sebagai berikut. 1) Bagaimanakah perencanaan pembelajaran pengetahuan dasar komputer berbasis blended learning? 2) Bagaimanakah implementasi pembelajaran berbasis blended learning untuk meningkatkan motivasi belajar? 3) Bagaimanakah implementasi pembelajaran berbasis blended learning untuk meningkatkan minat belajar? 4) Bagaimanakah implementasi pembelajaran berbasis blended learning untuk meningkatkan hasil belajar?

\section{Hakekat Pembelajaran}

Daryanto (2010: 2), belajar merupakan transmisi pengetahuan dari expert ke novice. Kutipan tersebut mengandung pengertian, bahwa peran pengajar adalah menuangkan dan menyediakan informasi yang berorientasi pada persepsi berhasil apabila peserta didik tunduk menerima pengetahuan yang disediakan pengajar.

Smaldino (2007: 10) menyatakan bahwa: "learning is the development of new knowledge, skill, or attitudes as an individual interact with information and the environment". Pembelajaran adalah pengembangan tentang pengetahuan baru, keterampilan atau sikap peserta didik secara individu pada saat berinteraksi dengan informasi dan lingkungan.

\section{Mata Kuliah Pengetahuan Dasar Komputer}

Mata kuliah Pengetahuan Dasar Komputer merupakan salah satu mata kuliah yang wajib ditempuh dalam Program Studi Agribisnis STIPER Amuntai. Mata kuliah ini memberi wawasan perkembangan komputer dan pemanfaatannya dalam mendukung pekerjaan sehari-hari, Di samping itu mahasiswa akan berlatih menggunakan berbagai aplikasi/ tools komputer dasar yang penting untuk menunjang pembelajaran dan karirnya, seperti: pengolah kata, pengolah angka, software presentasi, internet dan pembuatan blog.

Standar Kompetensi dasar antara lain sebagai berikut: 1) memahami dan mengkaji perkembangan komputer; 2) memahami dan mengkaji konsep dasar jaringan internet; 3) memahami dan mengkaji troubleshoot hardware dan software. 4) menggunakan Internet untuk pembuatan blog. 5) mengoptimalkan pemanfaatan pengolah kata dan pengolah angka serta mengoptimalkan pemanfaatan software presentasi.

\section{Blended learning}

Heinze A. (2008: 35) mendefinisikan "Blended learning is the delivery of teaching/ learning through the combination of online and face-to-face interaction resulting in improved student learning". Artinya blended learning pada dasarnya merupakan gabungan kombinasi pembelajaran yang dilakukan secara tatap muka (face to face learning) dan secara virtual (online). Pembelajaran online atau learning dalam blended learning menjadi perpanjangan dari pembelajaran ruang kelas tradisional yang menggunakan model tatap muka (face to face learning).

Dalam konsep blended learning diakui bahwa sumber belajar sebagai informasi yang disajikan dan disimpan dalam berbagai bentuk media, yang dapat membantu mahasiswa dalam belajar sebagai perwujudan dari kurikulum. Bentuknya tidak terbatas apakah dalam bentuk modul cetakan, video, format perangkat lunak atau kombinasi dari berbagai format yang dapat digunakan oleh mahasiswa dan dosen. Blended learning adalah suatu 
pendekatan yang fleksibel untuk merancang program yang mendukung campuran dari berbagai waktu dan tempat untuk belajar.

\section{Implementasi Learning}

Perancangan sistem learning perlu mempertimbangkan dua hal, yakni peserta didik yang menjadi target dan hasil pembelajaran yang diharapkan. Pemahaman atas peserta didik sangatlah penting, yakni antara lain adalah harapan dan tujuan mereka dalam mengikuti learning, kecepatan dalam mengakses internet atau jaringan, keterbatasan bandwidth, biaya untuk akses internet, serta latar belakang pengetahuan yang menyangkut kesiapan dalam mengikuti pembelajaran.

Implementasi sistem learning sangat bervariasi, namun semua itu didasarkan atas suatu prinsip bahwa learning dimaksudkan sebagai upaya pendistribusian materi pembelajaran melalui media elektronik atau Internet sehingga peserta didik dapat mengaksesnya kapan saja dari seluruh penjuru dunia.

\section{Motivasi belajar}

Motivasi adalah sebuah alasan atau dorongan seseorang untuk bertindak. Orang yang tidak mau bertindak sering kali disebut tidak memiliki motivasi. Alasan atau dorongan itu bisa datang dari luar maupun dari dalam diri. Robbins (2006: 213) mendefinisikan motivasi sebagai proses yang ikut menentukan intensitas, arah dan ketekunan individu dalam usaha mencapai sasaran. Sedangkan Rusman (2007: 118) menjelaskan bahwa "motivasi berarti menggerakkan kegiatan peserta didik dalam mempelajari modul, menggerakkan tugas-tugas dan mengikuti penilaian". Motivasi peserta didik dalam belajar akan sangat bergantung pada beberapa faktor, diantaranya: 1) komitmen; 2) antusiasme terhadap tugas; 3 ) keterampilan atau pengetahuan yang dimiliki untuk mengerjakan tugas; 4) keadaan fisik dan emosional peserta didik; 5) keadaan psikologis peserta didik; dan 6) lingkungan belajar.

\section{Minat Belajar}

Wijaya Kusumah \& Dedi Dwitagama (2010: 297-298) menjelaskan bahwa minat sebagai motif yang menunjukkan arah perhatian individu terhadap obyek yang menarik atau menyenangkannya, maka ia akan cenderung berusaha aktif dengan obyek tersebut. Pembelajaran yang dapat menarik minat belajar peserta didik adalah ketika pengajar dapat mengubah proses belajar yang membosankan menjadi pengalaman belajar yang menggairahkan. Indikatornya antara lain: 1) materi yang dipelajari dituangkan dalam media baru sehingga menimbulkan suasana baru sebagai variasi belajar; 2) materi pelajaran akan semakin menarik apabila peserta didik mengetahui tujuan dari materi yang dipelajari; dan 3) minat belajar dibangkitkan melalui variasi metode dan teknologi media pembelajaran yang digunakan.

\section{Hasil Belajar}

Lukita Yuniati (2007: 148) menjelaskan hasil belajar merupakan perubahan tingkah laku yang terjadi setelah mengikuti proses belajar mengajar sesuai dengan tujuan pendidikan. Pengaruh motivasi dan minat terhadap hasil belajar sangatlah besar. Motivasi dan minat adalah penggerak dari prestasi hasil belajar dan hanya bisa dicapai dengan tindakan. Hasil belajar mata kuliah pengetahuan dasar komputer merupakan tingkat kemampuan yang diperoleh individu setelah proses belajar berlangsung, yang dapat memberikan perubahan tingkah laku baik pengetahuan, pemahaman, sikap dan keterampilan mahasiswa sehingga menjadi lebih baik dari sebelumnya. Hasil belajar mata kuliah pengetahuan dasar komputer merupakan kemampuan kognitif hasil pencapaian yang diperoleh setelah pemberian proses pembelajaran tatap muka (face to face) dan pembelajaran online yang berupa nilai tugas dan kuis secara online.

\section{METODE}

Kegiatan penelitian ini menggunakan metode penelitian tindakan kelas (classroom action reseach) yang mengacu pada langkahlangkah penelitian model Kemmis dan McTaggart. Penelitian tindakan ini dilaksanakan dalam 2 tahapan yaitu tahap pembuatan media learning dan tahap implementasi pembelajaran melalui 3 siklus proses pembelajaran dengan partisipan mahasiswa Program Studi Agribisnis STIPER Amuntai yang menempuh mata kuliah Pengetahuan Dasar Komputer pada semester genap tahun akademik 2011/2012. Kegiatan siklus I meliputi perencanaan, tindakan, observasi, 
refleksi dan evaluasi. Kegiatan siklus II merupakan tindak lanjut dan modifikasi dari siklus I. Sedangkan siklus 3 adalah penyempurnaan dari siklus II. Adapun instrumen yang digunakan dalam kegiatan penelitian ini adalah lembar observasi tindakan/siklus, lembar observasi motivasi dan lembar observasi minat serta penilaian presentasi diskusi, kuis dan tugas.

Proses pengumpulan data menggunakan instrumen lembar pengamatan yang telah divalidasi sebelumnya dengan memberikan tanda checklist $(\sqrt{ })$ jika hal yang diamati muncul sesuai dengan pilihan. Teknik analisis data kualitatif digunakan untuk mendeskripsikan aktivitas mahasiswa dalam kegiatan pembelajaran. Tolak ukur keberhasilan bagi peserta didik secara praktis adalah dapat mengoperasikan internet dengan membuka alamat learning melakukan login, download materi, upload tugas, mengerjakan tugas mandiri, kuis online, aktif dalam forum diskusi dan menggunakan fasilitas chat/ message dalam berkomunikasi dan berinteraksi konsultasi dan secara otomatis mendapat umpan balik reward berupa nilai. Pengajar dan Peneliti mencatat dan mengamati segala aktivitas belajar mahasiswa sebagai data penelitian yang diharapkan dalam proses pembelajaran dapat meningkatkan motivasi, minat dan hasil belajar.

\section{HASIL PENELITIAN DAN PEMBAHASAN}

Tahap awal penelitian dilakukan kegiatan pembuatan desain media learning yang meliputi tahap perencanaan, tahap desain, tahap validasi ahli media dan tahap validasi ahli materi. Tahap perencanaan dilaksanakan dengan mengidentifikasi karakteristik kebutuhan media pembelajaran online dan mengidentifikasi sumber daya pendukung pembelajaran berbasis blended learning. Kemudian dilanjutkan tahap desain profil learning dengan melakukan beberapa langkah antara lain: a) pembelian domain dan hosting, b) pembuatan sketsa layout tampilan halaman learning, c) pembuatan flowchart untuk menggambarkan alur kerja learning, d) menentukan LMS (Learning Management System) yang digunakan, e) melakukan instalasi aplikasi moodle secara online. f) melakukan upload materi kuliah, g) melakukan validasi media dan h) melakukan validasi materi.

\section{Hasil Kegiatan Siklus I}

Kegiatan siklus I langkah-langkah perencanaan yaitu meliputi: a) analisis kebutuhan perkuliahan online, b) mengidentifikasi materi perkuliahan online, c) mempersiapkan materi sejarah teknologi komputer, d) mempersiapkan tugas materi sejarah teknologi komputer, e) mempersiapkan kuis materi sejarah teknologi komputer, f) mempersiapkan lembar observasi siklus 1, g) mempersiapkan petunjuk penggunaan learning Stiper amuntai, h) menyusun, mengatur dan mengunggah materi atau content learning ke alamat domain www.e-stiper.com, i) mendesain alat evaluasi dan penskoran penilaian dan $\mathrm{j}$ ) menentukan waktu pelaksanaan siklus 1 .

Tahap pelaksanaan meliputi: a) mensosialisasikan petunjuk penggunaan learning, b) menjelaskan petunjuk penggunaan learning berbasis moodle online, c) menerapkan learning berbasis moodle online dalam pembelajaran materi sejarah teknologi komputer, d) membimbing mahasiswa agar dapat mendownload bahan materi sejarah teknologi komputer yang disajikan, e) membimbing mahasiswa untuk aktif belajar mandiri dan mengerjakan tugas, f) mahasiswa dapat mengupload tugas, g) membimbing mahasiswa dapat mengerjakan kuis, h) memberikan umpan balik penilaian kinerja mahasiswa, i) mengamati pekerjaan mahasiswa secara online, j) memberikan beberapa pertanyaan kepada mahasiswa sebagai umpan balik penerapan dari learning.

Pengamatan aspek motivasi di kelas mahasiswa sangat antusias dalam memperhatikan petunjuk mendownload materi siklus I dengan rerata nilai 4,5. Kemudian juga sangat antusias dalam berlatih mendownload materi dengan rerata nilai 4,2. Mahasiswa sangat antusias memperhatikan petunjuk upload tugas dengan rerata nilai 4,4 dan antusias berlatih upload tugas dengan rerata nilai 3,8. Kemudian mahasiswa tampak sangat antusias memperhatikan dan berlatih penggunaan menu diskusi chat/message/inbox dengan rerata nilai 4,5 dan 4,2 .

Pengamatan aspek Minat pada kegiatan online menunjukkan mahasiswa sangat aktif dalam melakukan login membuka learning dengan rerata nilai 4,1 dan aktif melakukan 
download materi dengan rerata nilai 3,8 . Kemudian dalam kegiatan meng-upload tugas mahasiswa juga sangat aktif dengan rerata nilai 4,1 akan tetapi masih kurang tepat waktu dalam mengupload tugas dengan rerata nilai 3,1. Kemudian kegiatan online, mahasiswa tampak cukup aktif berinteraksi dengan dosen melalui pemanfaatan menu diskusi chat/ message/inbox walaupun kebanyakan berisi keluhan mengenai tugas yang belum terkirim atau sekedar memberitahukan bahwa tugas telah dikirimkan.

Hasil belajar berdasarkan standar penilaian STIPER Amuntai mengacu pada ketentuan yang ditetapkan maka hasil nilai belajar (tugas) pada siklus I rerata nilainya 74,18 masuk dalam kategori baik (B).

Hasil refleksi antara lain: 1) Implementasi www.e-stiper.com dalam pembelajaran materi sejarah teknologi komputer masih perlu perbaikan dengan mensosialisasikan dan menjelaskan petunjuk penggunaannya learning pada materi selanjutnya. 2) perlu disediakan fasilitas forum diskusi pembelajaran online. 3) Pengajar belum membuat kuis untuk evaluasi. 4) Belum melakukan pembatasan waktu mengumpulkan tugas. 5) Beberapa mahasiswa mengumpulkan tugas copy paste milik teman, sehingga perlu meningkatkan bimbingan mahasiswa agar belajar mandiri dalam mengerjakan tugas. 6) Mahasiswa masih kurang aktif dalam mengupload tugas.

\section{Hasil Kegiatan Siklus II}

Perencanaan Kegiatan siklus II disusun dari refleksi siklus I, kemudian dimodifikasi dan disempurnakan antara lain dengan: a) mempersiapkan materi sejarah ilmu komputer \& pengantar network, b) mempersiapkan tugas 2 materi sejarah ilmu komputer \& pengantar network, c) mempersiapkan kuis materi sejarah ilmu komputer \& pengantar network, d) menyusun, mengatur dan mengupload materi tugas dan kuis ke alamat domain www.e-stiper.com, e) membuat dan menyediakan fasilitas diskusi f) mengatur diskusi sebagai tempat mahasiswa melakukan posting tanggapan, g) menentukan batasan waktu mengumpul tugas, h) menentukan batasan waktu mengerjakan kuis, i) membimbing mahasiswa untuk mengerjakan tugas secara mandiri, dan j) membimbing maha- siswa untuk bertanya melalui fasilitas chat/ inbox di www.e-stiper.com.

Langkah-langkah kegiatan implementasi pada siklus II ini antara lain: a) menjelaskan petunjuk pengunaan content tugas, kuis dan group diskusi, b) membimbing mahasiswa dapat men-download materi sejarah ilmu komputer \& pengantar network, c) membimbing mahasiswa dapat mengupload tugas tepat waktu, d) membimbing mahasiswa dapat mengerjakan kuis dengan benar, e) membimbing mahasiswa dapat memberi tanggapan diskusi online, f) membimbing mahasiswa memanfaatkan bertanya melalui fasilitas chat/inbox, g) membimbing mahasiswa aktif belajar mandiri dan mengerjakan tugas secara mandiri, h) memberikan umpan balik penilaian kinerja mahasiswa, i) mengamati pekerjaan mahasiswa secara online, j) memberikan beberapa pertanyaan kepada mahasiswa sebagai umpan balik penerapan dari learning.

Pengamatan aspek motivasi Sebagaimana siklus I, mahasiswa sangat antusias dalam memperhatikan petunjuk mendownload materi siklus II dengan rerata nilai 4,6. Kemudian juga sangat antusias dalam berlatih men-download materi dengan rerata nilai 4,1 . Mahasiswa sangat antusias memperhatikan petunjuk upload tugas dengan rerata nilai 4,4 dan antusias berlatih upload tugas dengan rerata nilai 4,0. Mahasiswa tampak sangat antusias memperhatikan petunjuk mengerjakan kuis online dengan rerata nilai 4,0 dan antusias berlatih mengerjakan kuis online dengan rerata nilai 3,8 .

Pengamatan aspek Minat pada kegiatan online menunjukkan mahasiswa aktif dalam melakukan login membuka learning dengan rerata nilai 3,7 dan aktif melakukan download materi dengan rerata nilai 3,5. Kemudian dalam kegiatan meng-upload tugas mahasiswa sangat aktif dengan rerata nilai 4,3 dan tepat waktu dalam meng-upload tugas dengan rerata nilai 4,0. Kemudian kegiatan kuis online, mahasiswa tampak aktif mengerjakan kuis dengan rerata nilai 3,9 dan tepat waktu dengan rerata nilai 3,4. Mahasiswa menunjukkan keaktifan dalam berinterkasi dengan dosen melalui pemanfaatan menu diskusi chat/message/inbox dengan rerata nilai 3,2 .

Hasil belajar tugas dan kuis berdasarkan standar penilaian STIPER Amuntai 
mengacu pada ketentuan yang ditetapkan maka hasil nilai tugas pada siklus II rerata nilainya 75,53 masuk dalam kategori baik (B) dan hasil kuis rerata nilai 9,15 kategori sangat baik (A).

Hasil refleksi terhadap tindakan yang sudah dilakukan pada siklus II menunjukkan bahwa masih ada beberapa penyempurnaan yang harus dilaksanakan pada siklus berikutnya antara lain: 1) terjadi error pada website www.e-stiper.com, maka perlu tindakan restore program pada siklus III. 2) mahasiswa belum aktif memberi komentar pada forum diskusi. 3) beberapa mahasiswa masih belum tepat waktu dalam mengerjakan kuis 1. 4) beberapa mahasiswa kurang aktif dalam meng-upload tugas secara online. dan 5) ada beberapa mahasiswa belum memanfaatkan message/chat/inbox dalam interaksi konsultasi pembelajaran.

\section{Hasil Kegiatan Siklus III}

Perencanaan Kegiatan siklus III disusun dari refleksi siklus II, kemudian dimodifikasi dan disempurnakan antara lain dengan: a) mempersiapkan materi dasar network/jaringan dan internet, b) mempersiapkan tugas 3 materi dasar network/jaringan dan internet, c) mempersiapkan kuis 2 materi dasar network/ jaringan dan internet, d) menyusun, mengatur dan mengupload materi, tugas dan kuis ke alamat domain www.e-stiper.com, e) membuat dan menyediakan fasilitas diskusi, f) mengatur diskusi sebagai tempat mahasiswa melakukan posting tanggapan, g) menentukan batasan waktu mengumpul tugas, h) menentukan batasan waktu mengerjakan kuis, i) membimbing mahasiswa untuk mengerjakan tugas secara mandiri, j) membimbing mahasiswa untuk bertanya melalui fasilitas chat/inbox di www.e-stiper.com.

Pelaksanaan tindakan kegiatan pembelajaran pada siklus III relatif sudah stabil dan mahasiswa tampak lebih terbiasa, langkahlangkahnya antara lain: a) menjelaskan petunjuk pengunaan content tugas 3, kuis 2 dan group diskusi, b) membimbing mahasiswa dapat men-download materi dasar network/ jaringan dan internet, c) mahasiswa dapat meng-upload tugas 3 tepat waktu, d) membimbing mahasiswa dapat mengerjakan kuis 2 dengan benar, e) membimbing mahasiswa dapat memberi tanggapan diskusi online, f) membimbing mahasiswa memanfaatkan ber- tanya melalui fasilitas chat/inbox, g) membimbing mahasiswa aktif belajar mandiri dan mengerjakan tugas secara mandiri, h) memberikan umpan balik penilaian kinerja mahasiswa, i) mengamati pekerjaan mahasiswa secara online, j) memberikan beberapa pertanyaan kepada mahasiswa sebagai umpan balik penerapan dari learning.

Pengamatan aspek motivasi mahasiswa sangat antusias dalam memperhatikan petunjuk men-download materi siklus III dengan rerata nilai 4,8. Kemudian juga sangat antusias dalam berlatih men-download materi dengan rerata nilai 4,1. Mahasiswa sangat antusias memperhatikan petunjuk upload tugas dengan rerata nilai 4,5 dan antusias berlatih upload tugas dengan rerata nilai 4,0. Mahasiswa tampak sangat antusias memperhatikan petunjuk mengerjakan kuis online dengan rerata nilai 4,3 dan antusias berlatih mengerjakan kuis online dengan rerata nilai 4,0. Mahasiswa tampak sangat antusias memperhatikan dan berlatih penggunaan menu forum diskusi chat/message/inbox dengan rerata nilai 4,2 dan 4,1 .

Pengamatan aspek Minat pada kegiatan online menunjukkan mahasiswa aktif dalam melakukan login membuka learning dengan rerata nilai 3,9 dan aktif melakukan download materi dengan rerata nilai 3,9. Kemudian dalam kegiatan meng-upload tugas mahasiswa sangat aktif dengan rerata nilai 4,3 dan tepat waktu dalam meng-upload tugas dengan rerata nilai 3,9. Kemudian kegiatan kuis online, mahasiswa tampak aktif mengerjakan kuis dengan rerata nilai 4,0 dan tepat waktu dengan rerata nilai 3,5. Mahasiswa menunjukkan keaktifan dalam berinterkasi dengan dosen melalui pemanfaatan menu diskusi dengan rerata nilai 3,6 dan chat/ message/inbox dengan rerata nilai 3,7.

Hasil belajar tugas dan kuis berdasarkan standar penilaian STIPER Amuntai mengacu pada ketentuan yang ditetapkan, maka hasil nilai tugas pada siklus III rerata nilainya 80,29 masuk dalam kategori sangat baik (A) dan hasil kuis online rerata nilai 7,93 kategori baik (B).

Hasil refleksi terhadap tindakan yang sudah dilakukan pada siklus III menunjukkan bahwa secara umum telah terjadi peningkatan proses pembelajaran mata kuliah Pengetahuan Dasar Komputer ditinjau dari dari aspek keterlaksanaan oleh dosen, keterlaksanaan 
oleh mahasiswa, perhatian mahasiswa, keaktifan mahasiswa, bimbingan individual kepada mahasiswa, interaksi antara dosen dan mahasiswa, pemberian umpan balik secara kontinu. Adapun dari hasil data motivasi, minat hasil hasil belajar diperoleh data yang stabil dan mengalami peningkatan sesuai dengan indikator pencapaian.

\section{Ketercapaian Peningkatan Motivasi}

Peningkatan motivasi dalam penelitian tindakan kelas ini dapat dilihat pada grafik hasil analisis data akhir motivasi sebagai berikut.

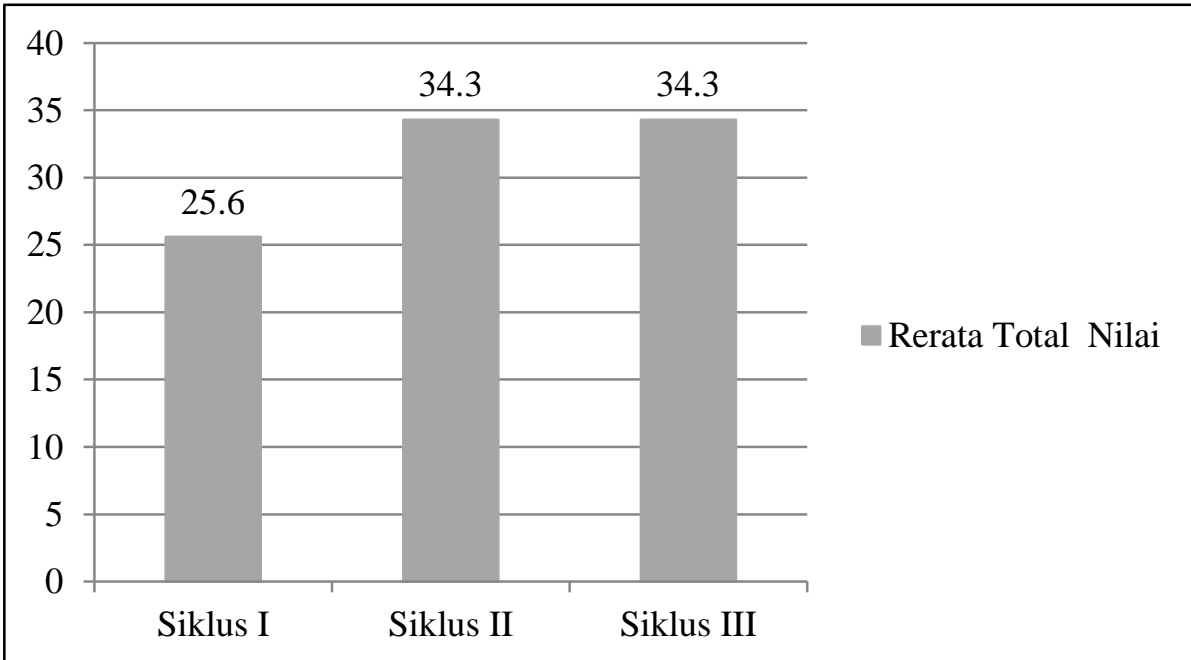

Gambar 1. Grafik Peningkatan Motivasi Proses Pembelajaran

Peningkatan motivasi tersebut tampak bahwa selisih antara rata-rata nilai siklus I dengan siklus II cukup jauh, tidak seperti pada siklus II dengan siklus III. Hal ini dimungkinkan terjadi karena mahasiswa baru pertama kali mengikuti pembelajaran online sehingga ketika ada beberapa mahasiswa yang kurang mengerti menjadikan dosen pengajar meningkatkan sosialisasi petunjuk penggunaannya. Namun demikian, secara keseluruhan dapat dikatakan telah terjadi peningkatan motivasi dari siklus I ke siklus II dan stabil pada siklus III.

\section{Ketercapaian Peningkatan Minat}

Peningkatan minat dalam penelitian tindakan kelas ini dapat dilihat pada grafik sebagai berikut.

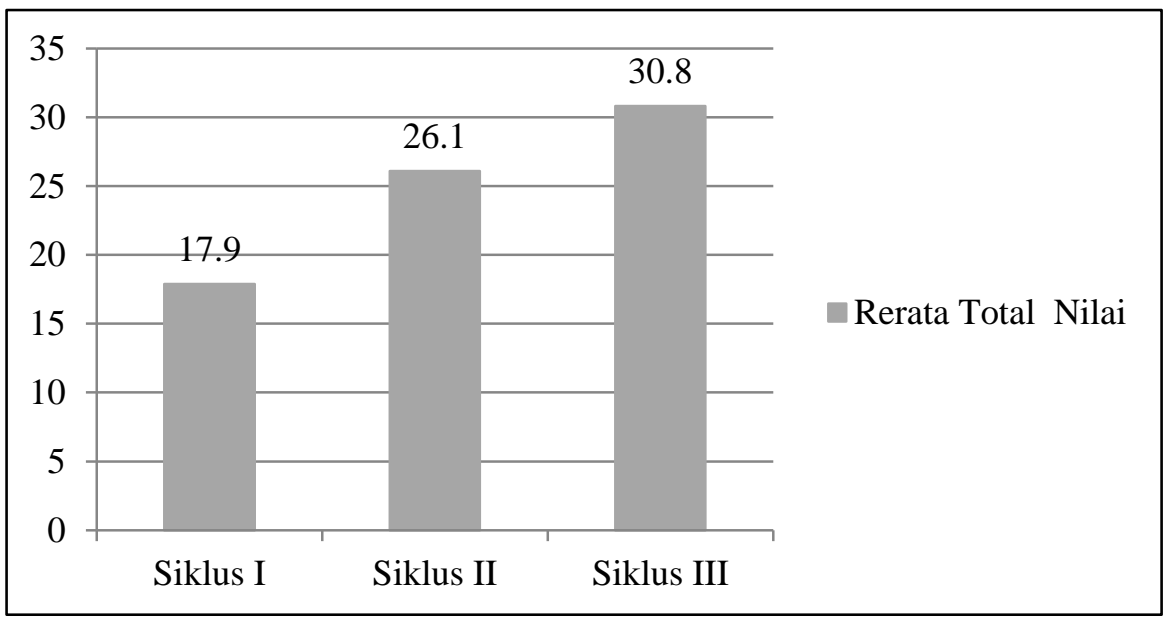

Gambar 2. Grafik Peningkatan Minat dalam Proses Pembelajaran 
Adanya peningkatan proses pembelajaran pada kelas online ini didukung dengan adanya pemberian materi dan tugas serta kuis secara online yang dirancang secara kontinu. Berdasarkan hasil observasi menunjukkan bahwa mahasiswa tampak berminat dengan bersungguh-sungguh aktif dalam mendownload, meng-upload, menyelesaikan tugas dan kuis dengan berusaha untuk selalu mengumpulkan tepat waktu. Selain itu, ke- sungguhan ini tampak pada keaktifan pemakaian laptop pribadi untuk forum diskusi, chat/inbox/massage dalam kelas atau diluar jam kelas yang selalu di pantau secara online.

\section{Ketercapaian Peningkatan Hasil Belajar}

Peningkatan hasil belajar dalam penelitian tindakan kelas ini dapat dilihat pada grafik hasil analisis data akhir sebagai berikut.

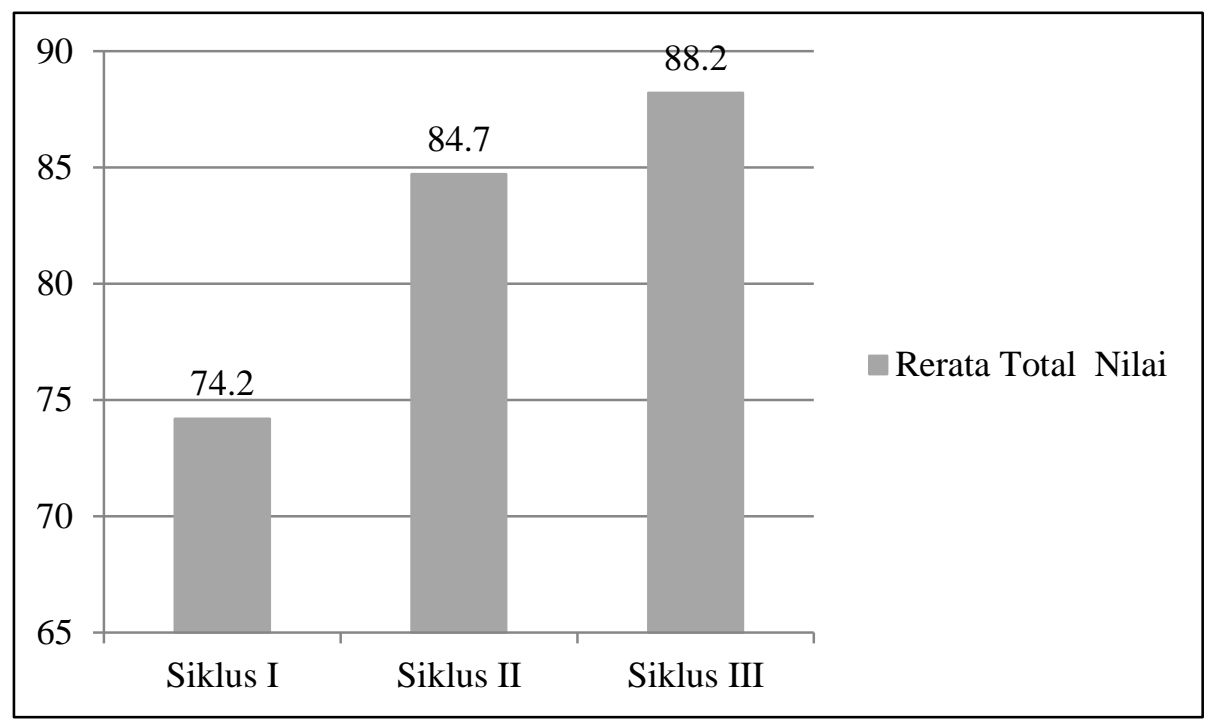

Gambar 3. Grafik Peningkatan Hasil Belajar

Peningkatan hasil belajar tersebut tampak bahwa selisih antara rata-rata nilai siklus I dengan siklus II cukup jauh, tidak seperti pada siklus II dan siklus III. Hal ini dimungkinkan terjadi karena pada siklus I nilai yang diambil hanya dari nilai tugas, sedangkan pada siklus II dan siklus III selain nilai tugas juga sudah dilengkapi dengan nilai kuis online.

\section{SIMPULAN DAN SARAN}

Pembelajaran pengetahuan dasar komputer berbasis blended learning dimulai dengan tahapan pembuatan media learning yang content isinya mengkombinasikan perkuliahan tatap muka dengan perkuliahan online. Kemudian melakukan validasi ahli media dan validasi ahli materi. Kegiatan tindakan setiap siklus meliputi antara lain: tindakan perencanaan, tindakan pelaksanaan dan observasi serta tindakan refleksi.

Pembelajaran berbasis blended learning menjadi salah satu solusi untuk meningkatkan motivasi mahasiswa pada proses pembelajaran mata kuliah pengetahuan dasar komputer. Peningkatan motivasi belajar tersebut tampak pada hasil total rerata nilai dari siklus I rerata nilainya 16,3 ke siklus II menjadi rerata nilai 18,3 dan stabil pada siklus III dengan rerata nilai 18,3 .

Peningkatan minat tampak pada aktifitas mahasiswa belajar didalam kelas dan tampak dalam proses pembelajaran online melalui beberapa aktivitas, antara lain: login, download materi, upload tugas, mengerjakan kuis online, dan menggunakan fasilitas chat/ message/inbox, forum diskusi serta partisipasi dalam kegiatan presentasi dan diskusi serta kehadiran kuliah tatap muka. Hasil total rerata nilai aspek minat dari siklus I yaitu 17,9 naik pada siklus II menjadi 26,1 dan pada siklus III naik menjadi 30,8.

Pembelajaran berbasis blended learning mampu meningkatkan hasil belajar mahasiswa yang rata-rata pernah memprogram mata kuliah pengetahuan dasar komputer sebelumnya dengan nilai kurang baik, sehingga dengan keaktifan tatap muka dan diskusi di 
kelas disertai proses belajar mandiri secara online, berdampak pada tercapainya nilai hasil belajar yang rerata nilainya dari siklus I yaitu 74,2 naik pada siklus II menjadi 84,7 dan pada siklus III rerata nilai meningkat menjadi 88,2.

Berdasarkan hasil penelitian dapat diajukan saran bahwa penerapan proses pembelajaran berbasis blended learning memerlukan kemauan dan pengorbanan yang besar, baik waktu, tenaga dan pikiran serta berkomitmen mengoptimalkan fasilitas yang tersedia seperti jaringan hotspot koneksi internet, LCD proyektor, laboratorium komputer, laptop dan multimedia untuk kepentingan peningkatan kegiatan pembelajaran. Dalam kegiatan yang bersifat tatap muka (face to face) maka pengajar dapat memanfaatkan learning untuk kegiatan remedial. Sedangkan dalam kegiatan online pengajar dapat mempersiapkan materi pembelajaran selama satu semester. Sehingga seandainya dosen berhalangan mengajar, maka kegiatan pembelajaran akan tetap berjalan melalui kegiatan online.

\section{DAFTAR PUSTAKA}

Daryanto, (2010). Media Pembelajaran. Yogyakarta: Gava Media.

Heinze, A. (2008). Blended Learning: an Interpretive Action Research Study. http://usir.salford.ac.uk/1653/1/Heinze_ 2008_blended_learning.pdf, artikel diambil pada tanggal 25 Juni 2012. University of Salford, Salford.

Lukita Yuniati (2007) Penelitian Tindakan Kelas: Meningkatkan Hasil Belajar Fisika dengan Pembelajaran Kooperatif Berbasis CD Interaktif dengan Kombinasi Tutor Sebaya pada Siswa SMAN 7 Semarang. Jurnal Teknodik. No. 20/X/Teknodik/April/2007.

Robbin, S. P. (2006). Perilaku Organisasi. (Terjemahan Benyamin Molan) New Jersey: Pearson Educational International. (Buku Asli diterbitkan tahun 2003).

Rusman (2007) Implementasi Model Pembelajaran Berbasis Komputer Untuk Meningkatkan Kompetensi Siswa pada Mata Pelajaran Matematika di SMK. Jurnal Teknodik. No. 21/X/Teknodik/ Agustus/2007.

Smaldino, S.E., Lowter, D.L., \& Russell, J.D et al. (2007). Instructional technology and media for learning. New York: Pearson Merrill Prentice Hall.

Wijaya Kusumah, \& Dedi Dwitagama. (2010). Mengenal Penelitian Tindakan Kelas, Jakarta: PT. Indeks. 